\title{
There's Work to be Done: Exploring Library-Vendor Relations
}

\section{Authors: Kristen Ostergaard, Doralyn Rossmann}

This is a preprint of an article that originally appeared inTechnical Services Quarterly in

December 12, 2016. http://www.tandfonline.com/doi/full/10.1080/07317131.2017.1238196

Kirsten Ostergaard \& Doralyn Rossmann (2017) There's Work to be Done: Exploring Library-

Vendor Relations, Technical Services Quarterly, 34:1, 13-33, DOI: 10.1080/07317131.2017.1238196

Made available through Montana State University's ScholarWorks 


\section{There's Work to be Done: Exploring Library-Vendor Relations}

Kirsten Ostergaard \& Doralyn Rossmann

Kirsten Ostergaard \& Doralyn Rossmann (2017) There's Work to be Done:

Exploring Library-Vendor Relations, Technical Services Quarterly, 34:1, 13-33, DOI: 10.1080/07317131.2017.1238196

http://dx.doi.org/10.1080/07317131.2017.1238196

\section{Abstract}

Academic library and vendor professionals were surveyed to determine strengths and weaknesses of these relationships-revealing, in some cases, conflicting priorities. The two groups offered perspectives on communication preferences, organizational strategies, priorities, and local challenges. Trends emerging from the survey results highlight a need to explore the library-vendor relationship further. This article will be of interest to academic librarians and staff working regularly with vendors in acquisitions or collection management.

\section{Introduction}

Academic librarians and staff in collection-development and acquisitions routinely work with vendors in order to learn about new products, trial and acquire database collections, maintain subscriptions, and troubleshoot access problems. As library collections are increasingly electronic, vendor-hosted, and growing in volume and breadth, the likelihood and frequency of communicating with vendors increases. Consequently, library and vendor relationships are evolving. Given these changes in the management and acquisition of electronic resources, there is a need to evaluate library- vendor relationships.

In order to assess the library- vendor relationship, the researchers crafted two online surveys: one for academic library librarians and staff, and another for vendors. The surveys were designed to reflect the higher education environment in the United States. Therefore, the call for participants was intended for individuals working for libraries in the United States and for vendors doing business with academic libraries in the United States. With the survey results, the researchers set out to answer:

- How do academic libraries organize and manage vendor relations?

- What challenges do academic libraries face when working with vendors? 
- How do vendors organize and manage library relations?

- What pressures do vendors face when working with libraries?

The initial motivation for evaluating library- vendor relations stems from a local need to address challenges; namely, the time commitment and communication mechanisms in place with vendors at the Montana State University Library. The collection-development department at the Montana State University Library routinely works with over 50 vendors to provide access to various information resources including electronic journals, eBooks, databases, streaming-media collections, and datasets. These vendor communications include sales calls, database renewals, product or platform upgrade information, journalissue highlights, site visits, conference meetings, and technical access issues. As departmental responsibilities grow and change, it is important to review vendor relations practices and how libraries manage these relationships. This study attempts to understand the goals of the library- vendor business relationship and proposes some best practices for libraries and vendors to use in maintaining these relationships.

In this article, the term "vendor" is used to describe publishers and content aggregators and their employees such as sales representatives, account managers, sales directors, and marketing directors. These job titles reflect survey respondents' positions held at vendor companies. Additionally, the term "librarian" is used to represent the potential range of library professionals interacting with vendors including librarians, professionals, and classified staff.

\section{Literature review}

Researchers and practitioners look to literature on the library-vendor relationship for analysis of relationship trends and an assessment of professional practices. Discussion has thus far focused on three key points: the nature of communication, disconnect in perceived benefits, and suggestions to improve librarian-vendor relationships.

The nature of the communication may have an effect on the librarian and vendor. The preferred communication style varies for many librarians depending on if it is about the vendor providing a good or a service. Here, a "good" is a journal article, database, eBook, and so on that a vendor provides to a library. A "service" by vendors would be setting up and troubleshooting access to subscriptions, answering questions, and so on. Regarding a good, Tenopir (2005) observed, "One message is clear: librarians do not want to hear about new products over the telephone" (p. 42). Conversely, when librarians want customer service, they want it now. Considering a service, Flowers (2004) noted:

If the vendor does not provide excellent service, the acquisitions staff will have much extra unnecessary work. Time is money and even a cheap price cannot make up for the time libraries spend acquiring or maintaining products from vendors with poor customer service. (p.436)

Raley and Smith (2006) echoed this sentiment: 
A growing and disturbing phenomenon is the inability to obtain immediate technical support because the vendor requires that all technical support questions be e-mailed. Being unable to get immediate phone assistance can be a major problem for a college that is without access to their purchased databases. (p. 195)

They go on to say that regarding goods, "librarians share ... concerns regarding relationships with vendors. Most prefer communication via e-mail over telephone sales calls" (Raley \& Smith, 2006, p. 199). For Courtney (2006), the strength of library- vendor relationships is "a direct reflection of the commitment of each party to the continuing development of academic research and the benefits it fosters" (p. 58). Understanding what kind of communication is wanted by libraries at what time and in what context is important for library- vendor relations.

Data Planet conducted a survey of librarians' sentiments on vendor relations at the 2014 Charleston Conference. The survey revealed a disconnect in the librarian- vendor relationship. It found $71 \%$ of respondents view vendors as partners rather than adversaries or competitors. Yet when asked in the same survey, "How did you do in your most recent difficult negotiation?", 60\% of respondents were unhappy with the results (Gruenberg, 2014). These results revealed a perceived disconnect in the benefits to the library of the partnership. For librarians working with many vendors, the disconnect may stem from a lack of some vendors' procedural transparency and effective infrastructure. Kitchen (2011) noted it is a challenge to manage communication preferences with vendors who are overly aggressive or fail to understand the products they are trying to sell. Likewise, she wants the flexibility of online invoicing and order checking that is not met by many vendors, and made worse in broken promises for such functionalities. One person (Remy, 2013) representing the vendor world explained there are disparate and sometimes outdated systems in place to manage different aspects of the publishing and database business-from invoicing to collection management and customer service queries. Shared experiences like these are of value because they expose possible sources of disconnection as well as operational challenges experienced by both librarians and vendors.

The literature provides suggestions for librarians to improve the librarian- vendor relationship including preparing in advance of a vendor meeting, being assertive in negotiations yet not unreasonable, and treating vendors respectfully (Anderson, White, \& Burke, 2005). Other recommendations stress the importance of listening, and having polite and respectful communication for profitable interactions on both sides (Ginanni, McKee, Wilson, \& Brown, 2015). Periodic check-ins with honest conversation between vendors and librarians provide an opportunity for reflection and evaluation of these relationships. With this information, there are opportunities to address challenges and improve workflow for mutual understanding. For Walther (1998), "how librarians evaluate vendors and how this information is communicated is intrinsically connected to the success or failure of the library- vendor relationship" (p. 149). The evaluation of products for quality and service informs the vendor evaluation, and communication is critical to the success of any future relationships. 


\section{Methodology}

Two surveys were designed: one intended for vendor professionals and the other for library professionals in the United States. The surveys asked a mixture of qualitative and quantitative questions to reveal workplace operations, commitments, and pressures. These surveys were pre-tested with vendors and librarians known to the researchers to ensure clarity and relevancy of questions and to gauge understanding of librarian and vendor terminology. Final versions of the surveys were announced on the College Librarians List (Colllib-L), Electronic Resources in Libraries Email List (ERIL-L), LIBLICENSE, the Scholarly Communication Email List (ScholComm), and the Serials in Libraries Discussion Forum (SERIALST) email lists and were available from Thursday, November 12, 2015 to Wednesday, December 16, 2015.

The email call outlined the types of respondents sought to complete the survey using the following text: "We invite you to participate in a survey that explores the library- vendor relationship. One survey is intended for academic library professionals that routinely work with vendors, while the other is intended for vendor professionals that routinely interact with academic libraries." See Appendices A and B for copies of the surveys.

\section{Results}

The vendor survey consisted of 19 questions and received a total of 35 responses. The library survey consisted of 19 questions and received 164 responses. Of the 164 respondents, six resided outside of the United States. These responses are excluded from the results set because of differing organizational systems and educational structures. In both surveys, all questions were optional.

\section{Demographics}

The survey call asked for vendor professionals who regularly interact with academic libraries. The resulting respondents ( $N 1 / 435)$ identified their job titles in categories such as sales representative, account manager, marketing and sales, and library relations. Of these respondents, 33\% (N 1/4 19) have worked in a library at some time, and $41 \%$ have a master's degree in library and information science or equivalent degree.

Of academic library respondents, 58\% (N 1/4 158) were from public institutions, and $42 \%$ were from private ones. Collection budget size for libraries ranged from at least $\$ 50,000$ to over $\$ 10$ million (see Figure 1 ).

Doctoral-granting universities made up the majority of library types when using Carnegie classifications (51\%), with master's colleges and universities second (26\%), followed by baccalaureate colleges (15\%), associates colleges (4\%), and special focus institutions (4\%). No tribal college libraries participated in the survey. Nearly all libraries (93\%) report acquiring resources both independently and through consortia 


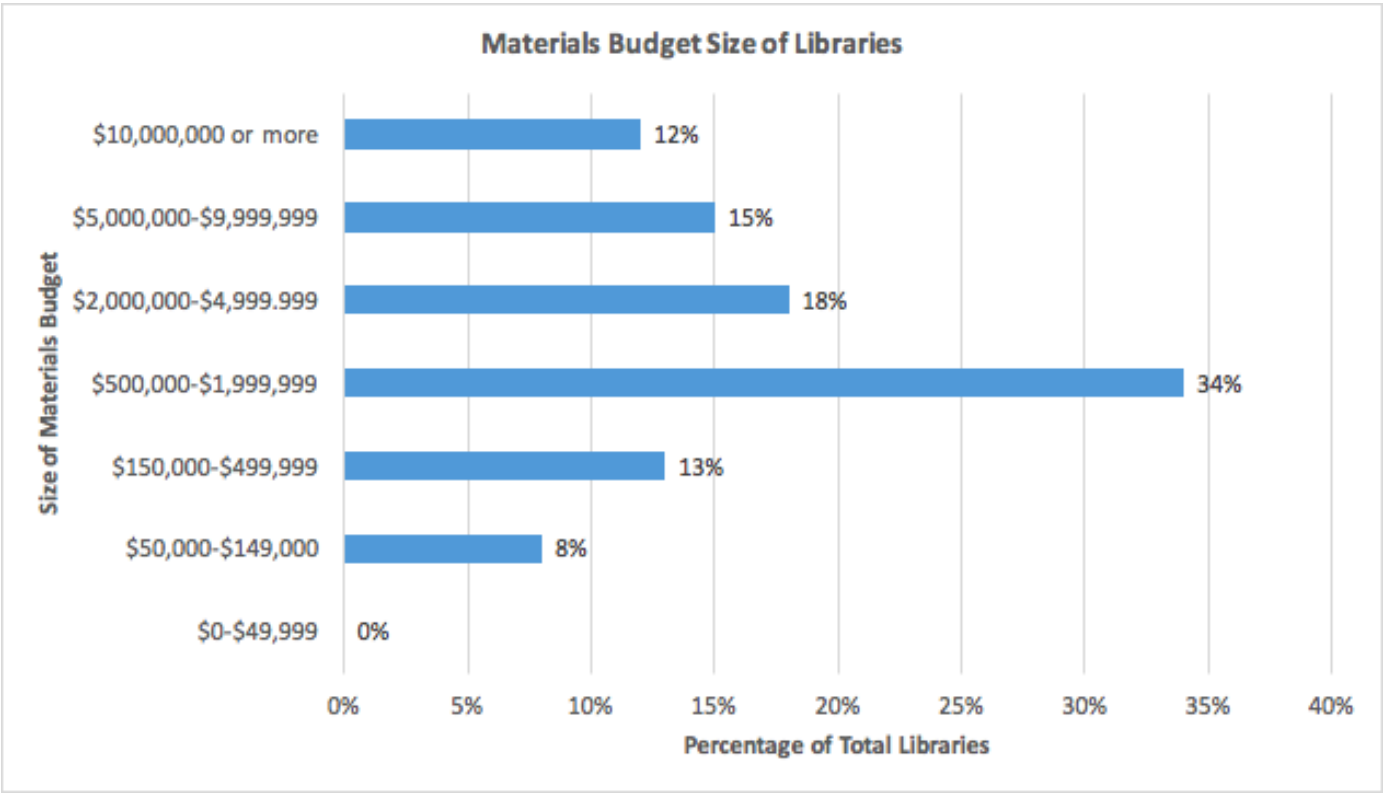

Figure 1. Size of fiscal year 2016 library materials budget of academic librarian respondents.

\section{New Relationships and Contact Points}

Most libraries have more than one employee communicating with vendors, with over $42 \%$ of respondents indicating five or more people at their libraries do so. Of respondents, $48 \%$ work with 25 or more vendors.

When vendors seek to learn more about the libraries with which they are working, the majority look at the library's website, review the library's purchasing history, and talk directly to librarians. Conferences and the news are also sources of information (see Figure 2).

New vendor representatives rely heavily on internal databases for learning about existing customers (96\%) and $71 \%$ receive some form of cross-training from representatives previously assigned to that customer.

Where Vendors Get Information about Libraries
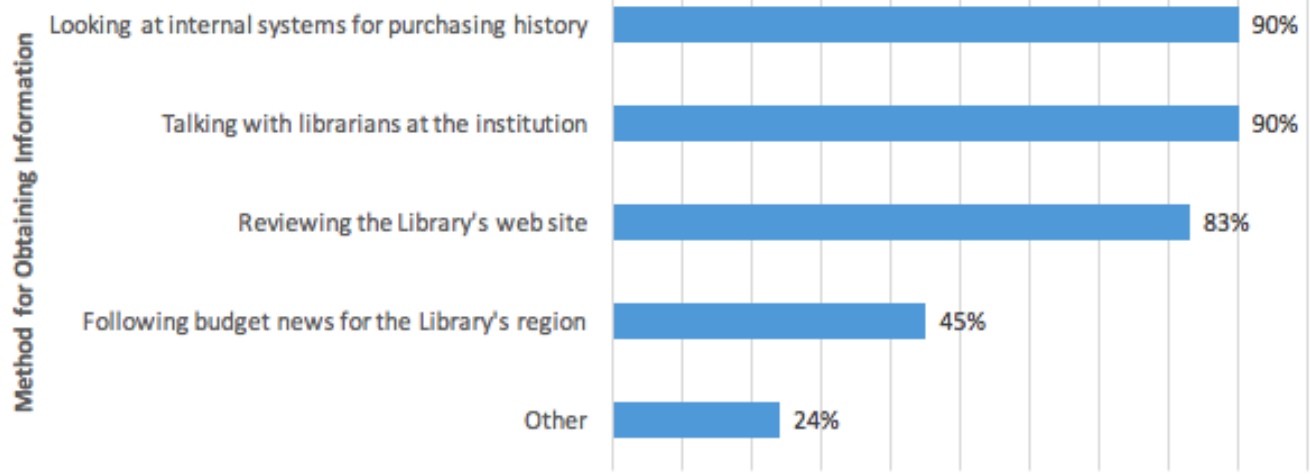
Figure 2. How vendors gather information about their customers.

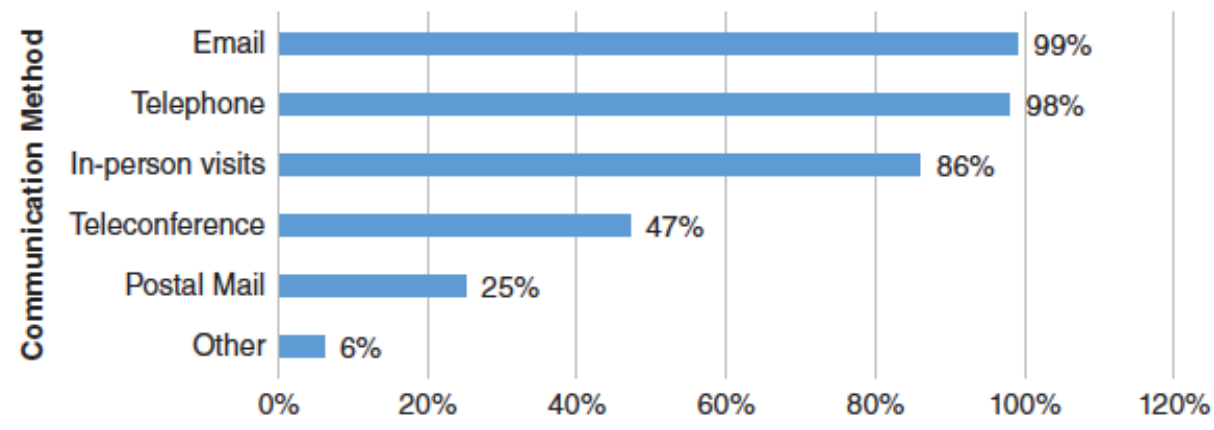

Percentage of Librarians Using This Method

Figure 3. Means of communication that libraries use with vendors.

\section{Communication types and preferences}

Practically all librarians communicate with vendors both via email and telephone (99\%), and most have in-person meetings with vendors (86\%; see Figure 3 ).

On the vendor side, respondents' companies prefer representatives use email (83\%), telephone $(72 \%)$, and meetings at conferences $(79 \%)$ to contact library customers.

Librarians' preferred forms of communication vary depending on the reason for the communication. When librarians were asked what form of communication with vendors is preferred by activity type, email is by far the most popular in all categories, except when troubleshooting access problems, where telephone (68 respondents) is almost equally preferred to email (76 respondents; see Table 1 ).

Postal mail and telephone lead in the "least preferred communication" means for libraries when working with vendors, except when troubleshooting access where telephone is more favorable than the other activity types (see Table 1).

Not all vendors gauge these communication preferences of libraries. When asked "When working with new customers, do you routinely determine their preferred method of communication?", 63\% of vendors said "yes," 7\% said "no," and 30\% said "I only gather this information if it is suggested by the library."

\section{Librarian - vendor meetings}

Vendors and librarians often meet at conferences or at the library. The purposes of these meetings are not that different between the two groups. 
Table 1. Most and least preferred forms of communication by libraries with vendors by activity type.

\begin{tabular}{|l|l|l|}
\hline Communication Activity & $\begin{array}{l}\text { Most } \\
\text { Preferred }\end{array}$ & Least Preferred \\
\hline $\begin{array}{l}\text { Receiving Information about new } \\
\text { resources }\end{array}$ & Email & Telephone \\
\hline $\begin{array}{l}\text { Inquiring of vendor about new } \\
\text { resources }\end{array}$ & Email & Postal Mail, Telephone \\
\hline Setting up trial resources & Email & Postal Mail, Telephone \\
\hline $\begin{array}{l}\text { Receiving new or updated license } \\
\text { agreements }\end{array}$ & Email & Telephone \\
\hline Troubleshooting access problems & Telephone, & Postal Mail \\
\hline Receiving an invoice & Email & Postal Mail \\
\hline Training and marketing & Email & Telephone, Postal Mail \\
\hline
\end{tabular}

Table 2. Most important and least important in what librarians and vendors hope to gain in meetings with each other.

\begin{tabular}{|l|l|l|}
\hline $\begin{array}{l}\text { Communication } \\
\text { Activity }\end{array}$ & Most Important & Least Important \\
\hline Libraries & $\begin{array}{l}\text { Providing feedback to vendor on } \\
\text { existing products and services, } \\
\text { Negotiating prices }\end{array}$ & $\begin{array}{l}\text { Socializing with } \\
\text { vendor } \\
\text { representatives }\end{array}$ \\
\hline Vendors & $\begin{array}{l}\text { Making sales, Getting customer } \\
\text { feedback on existing products } \\
\text { and services }\end{array}$ & $\begin{array}{l}\text { Socializing with library } \\
\text { employees }\end{array}$ \\
\hline
\end{tabular}

Librarians hope to negotiate prices; to convey library information, technology, and priorities to vendors; and to provide feedback to vendors of existing products and services. Socializing with vendor representatives is the lowest priority for librarians (see Table 2).

But, when asked if they communicate these preferences and hopes for meetings to vendors prior to the meetings, $51 \%$ of librarians said "no" and $49 \%$ said "yes."

Vendors have their own preferences when meeting with librarians (see Table 2), which is largely about "making sales" and not about "socializing with library employees." This preference may be further informed by the pressures vendors face in their work, with a majority saying they face the pressures in all areas of our 
survey question (see Figure 4). It seems the co-existing service orientation of libraries to provide resources and services to library users and vendor pressures to make contact with and sales to customers can be at odds with one another.

To get more context for the quantitative responses, it is useful to review the comments made in the free-text questions posed of librarians and vendors. As noted earlier, $83 \%$ of vendors refer to library websites for information about their customers (the library). When vendors were asked, "What would help you better understand a library's specific needs?", a sampling of free-text responses include: "Understanding the prioritization of collection-development and the decisionmaking process for new acquisitions."

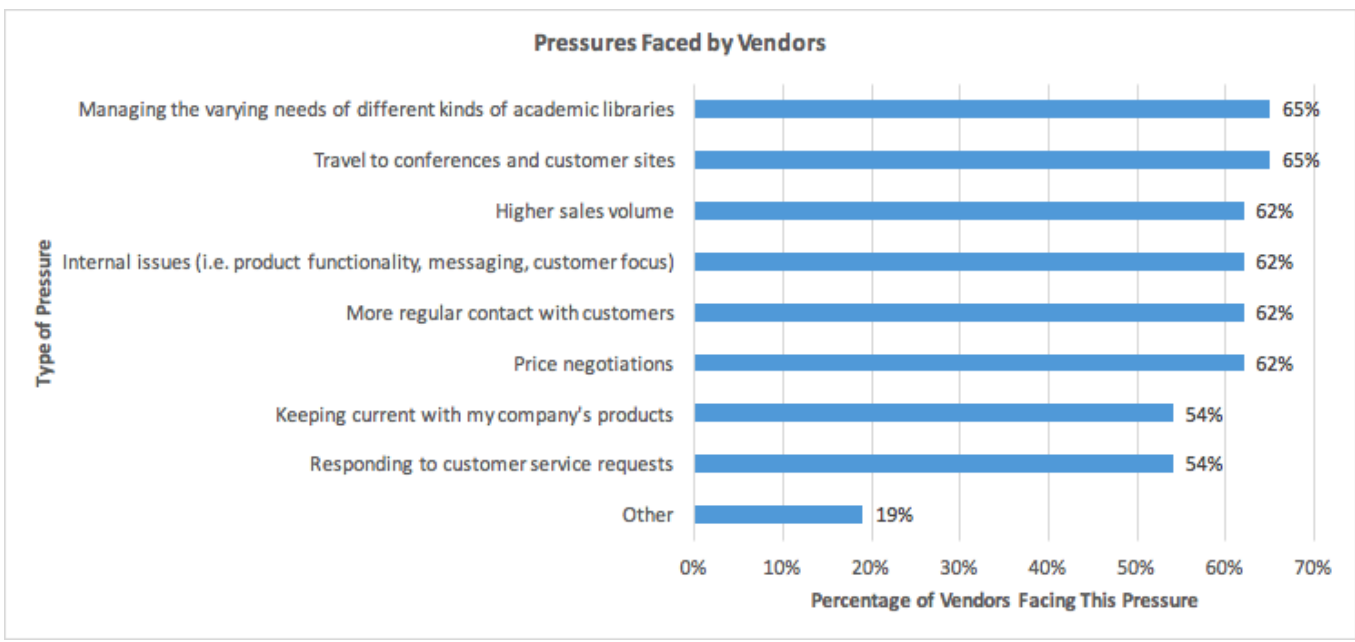

Figure 4. Pressures vendors face in their work.

"Annual meetings that cover both short-term ( 1 year) and long-term ( $3-5$ years) library plans and initiatives."

"Web sites that are easier to navigate; time with librarians to discuss needs"

"More demographic information, ILS system used, curriculum growth areas"

From these comments, it seems vendors want to spend time with librarians to understand their needs, processes, and priorities.

Though one of the goals of vendors is to make sales, they also want to provide service, make the best use of their time, and serve libraries. When asked, "What would help you more efficiently understand a library's specific needs?", a sampling of free-text responses read:

"I always appreciate when librarians are honest with me, whether the feedback is good or bad. Any response is always appreciated! And it helps me know what to bring to their attention when the time is right."

"Clear communication path [between] ... the decision makers and the technical implementers"

"Let me know what works for you. Do you prefer phone or e-mail? Do you want specific sale information, or want to know about anything new? etc."

"Information on [library] web sites (under Acquisitions or Collections?)"

Again, vendors want to hear from librarians, and they want honesty and clarity. 
Any communication from librarians is more satisfying than no communication at all. With this information in hand, an analysis of these results and possible recommendations are provided.

\section{Discussion}

\section{About librarians}

Libraries will want to consider how they portray themselves on the web and what information they provide for the vendor doing research on them. As the survey results suggest, vendors want more access to library information, priorities, goals, and collection-development strategies. They also want quick facts about the university including degree programs and research areas. Vendors indicate they are looking for this information without always asking libraries directly about their local circumstances or needs, so libraries may be misunderstood by vendors if information is inaccurate or absent altogether.

The survey results point unquestionably to a library preference for email communication with vendors in all areas except for troubleshooting access. Given the high volume of people communicating with vendors per library-in addition to the high volume of vendors with which many libraries work-it

seems logical that email is a preferred form of communication. When many people per library speak routinely with vendors, and academic librarians work with a multitude of library vendors, email allows for easier communication, tracking, and sharing.

Librarians indicate a preference for telephone conversations in instances in which technical issues present access problems for the patron. Likely, this is because academic libraries are in the business of providing a service. When that service is compromised, it affects the education and research of students and faculty. Therefore, it is important for libraries to restore access as quickly as possible. One of the most effective ways to accomplish this is to contact a vendor by telephone. Librarians will want to examine if they are clearly expressing to vendors their priority for quick telephone support for troubleshooting access issues.

Librarians could do a better job of relaying communication preferences to vendors. When asked how this is done, one respondent answered, "in the most passive and ineffectual way: missed calls, respond back via email. [1] hope they take the hint ... [I] just don't have time for a phone call". Likewise, many librarians do not let vendors know what they would like to discuss when planning in-person meetings. When asked if library personnel communicate meeting priorities to vendors, $51 \%$ of librarians do not, whereas $49 \%$ do.

\section{About vendors}

Vendors gather information about clients referencing library websites, internal systems for purchasing history, or speaking with librarians. Vendors want to understand their customers better, but they do not unilaterally ask about how libraries want to communicate or what they hope to gain from in-person meetings. Furthermore, one vendor objective is to sell products and/or 
subscriptions. Vendors may consider how the method of communication affects customer relations and sales in addition to what forms of communication are most meaningful for the customer.

When vendors experience turnover in representatives, vendors may be inconsistent in tracking information to new representatives or between representatives representing different parts of a larger company. With a heavy reliance on internal databases for communication of information about existing clients, vendors may review the information captured and communicated between vendor personnel.

There is an inherent conflict found in the preferences for vendors to spend time discussing needs of the library through means other than email and the interest of libraries to limit regular communications outside of email. Libraries seem to have a preference to communicate via email, and vendors seem to want to have discussions via telephone or in-person to gain insights into libraries.

This tension presents challenges with library- vendor communications. Vendors have their own sets of pressures which may be largely unknown to, unrecognized by, or of no concern to libraries. An inherent tension exists with libraries serving in a service model and as a customer to vendors, while vendors have expectations from the corporate environment, which may be foreign to the academic library world.

\section{Recommendations: For librarians}

\section{Website for vendors}

If vendors are referencing library websites, there is an opportunity for libraries to create a web page including information specifically for vendors. This sort of web page could then be easily referenced by librarians during meetings and shared directly with vendor representatives via email. In addition to housing local library data and goals, a web page specifically intended for vendors could relay guidelines for communication preferences and primary library contacts. Also, as vendors merge, reassign territory, promote employees, and have employee turnover, a library web page (as a part of the larger library website) designed with vendors in mind can reduce the time spent re-educating the same vendors about preferences. With this information easily accessible on a library's website, it may minimize the need for telephone conversations, which, according to survey results, librarians prefer to reserve for troubleshooting access problems.

\section{Shared email alias}

Multiple people per library are routinely interacting with vendors. One strategy for inclusive email communications is the use of a shared email address for appropriate parties in the library. In order to manage shared communication with vendors, the collection-development department at the Montana State University Library employs the use of a shared email address alias (Ostergaard \& Rossmann, 2016). This email alias distributes vendor email to the Head of Collection Development, the Electronic Resources and Discovery Services Librarian, and a Serials Coordinator-all of whom are in regular contact with 
vendors, relative to trialing and acquiring new e-resources, billing, and ensuring access. A shared email address reduces missed or redundant communications, which occurs more often when vendors communicate directly with individuals.

\section{Vendor email folders}

About half of library survey respondents (48\%) work with more than 25 vendor companies. With so many vendors providing critical resources for patrons, it can be difficult to track communications about new products, platform upgrades, or troubleshooting correspondence. One strategy for managing the organization of email communication is the use of email folders designated for each vendor (Ostergaard \& Rossmann, 2016). Establishing a habit whereby librarians and staff automatically sort and organize vendor emails into folders makes for easy search and retrieval.

\section{More direct communication about expectations}

As is evident from vendor responses, librarians need to have honest and direct communication with vendors about goals, pressures librarians face, and desired service if they want vendors to understand their needs. Librarians would be wellserved to be more forthcoming and disclose communication and relationship preferences. Likewise, priorities for in-person meetings should be shared with the vendor prior to the meeting for clear understanding of the meeting's purpose. Time spent in face-to-face conversations between librarians and vendors can be more productive if both parties work to establish a mutually agreed-upon meeting agenda.

\section{Recommendations: For vendors}

\section{Ask for library communication preferences}

Many vendors do not proactively solicit library communication preferences. This may result in a misunderstanding when little or no response is received from libraries. If all vendors adopted a routine policy to ask libraries about their preferred communication channels, libraries might be more receptive to the contact from vendors.

\section{Record communication preferences}

Vendors would benefit from logging communication preferences and key contacts of clients in a database or customer-management system. In cases where representatives of large vendor companies represent different types of collections, customer information would be centrally accessible to many vendor employees. Another benefit of storing customer contacts and communication preferences is that it can be easily referenced in times of personnel turnovereasing the transition of a new vendor representative into his/her role.

\section{Respect library communication preferences}

When librarian communication preferences are repeatedly ignored and overwhelming, it can be perceived as a sign of disrespect that can damage customer relations. Vendors are encouraged to respect library communication 
preferences and time commitments. There may also be an occasion for vendors to honestly share communication requirements with libraries. For example: In some cases, vendors are required to make contact with librarians once a month.

If librarians are aware of this requirement and understand there is no pressure to necessarily respond, the repeated contacts need not be interpreted as flippant, but rather with a greater understanding of vendor operational pressures.

\section{Manage vendor pressures}

Vendors face pressures to provide quality, usable, informational resources with the technical support and infrastructure necessary to guarantee ongoing access as well as sales. Vendors rely on librarians and users to provide product feedback that informs the improvement of their products, and thus business. Perhaps vendors can consider the means by which they seek product evaluation in ways that align with librarian communication preferences. One example might be to offer discounts for libraries on their subscriptions if they complete an email or web survey about a vendor product or service.

\section{Limitations}

These surveys were distributed to several email lists to solicit responses. The original library survey call was to academic libraries and asked for Carnegie classifications: a system unique to the United States. This survey was intended to gauge experiences of libraries based in the United States with vendors located anywhere. These results could be further informed by experiences and perspectives in other parts of the world. Of the U.S. academic libraries, results indicate no responses were received from tribal college libraries, which could have been contacted more directly for their perspectives.

There was broad national participation in the library survey. Under- represented states with no participants include Alaska, Delaware, Hawaii, Nebraska, Nevada, Oklahoma, Rhode Island, South Dakota, Washington, and Wyoming. The states with the highest response rates include California, Ohio, and Texas, each with 6\% survey representation, and New York with 7\% representation.

While the literature suggests focus groups and advisory boards also serve as communication channels between libraries and vendors, this article focuses on daily library- vendor communications. It should be noted focus groups and advisory boards serve as other ways these groups communicate, but were beyond the scope of this study.

\section{Future considerations and concluding thoughts}

The library- vendor relationship is frequently reviewed for optimization of effort on behalf of both parties. Routine evaluation has the promise of returning a favorable partnership ultimately designed to benefit library patrons. This study provides further insight into the library- vendor relationship and raises more questions for additional evaluation. For example, it would be interesting to know how many site visits result in new sales for vendors. If very few sales are generated, then perhaps the practice of in-person visits is outdated. Also, with the 
growth of the open-access (OA) movement in publishing, are there new challenges posed to libraries regarding demands on their time in keeping up with new organizations (such as Sponsoring Consortium for Open Access Publishing in Particle Physics (SCOAP3) and Knowledge Unlatched) and to vendors in communicating options offered by their companies regarding OA? Another area of interest is the effect library budgets have on communications from year to year. Does budget growth or reduction change communication preferences or needs in libraries? Finally, as vendor companies merge, how does information about customers get transferred between these newly formed partnerships? Are there opportunities for vendors to look at internal processes to consolidate customer information to reduce redundancies in communications to libraries?

Libraries have a directive to provide a high-quality service and access to informational resources for their users. Vendors have a goal of selling quality products. To that end, libraries and vendors need each other. Rather than competing, an opportunity exists to complement and learn much from one another (Carlson, 2006). Communication is a key component to any successful partnership. Both parties should consider the findings of these surveys and how improvements in communication could be made for the maximum benefit of the time spent in these relationships. With ever-growing electronic collections, effective library- vendor relationships are critical for the success of library services, vendor profitability, and-most importantly-library users.

\section{References}

Anderson, R., White, J. F., \& Burke, D. (2005). How to be a good customer. The Serials Librarian, 48(3-4), 321 - 326. doi:10.1300/J123v48n03_15

Carlson, D. H. (2006). Introduction. Journal of Library Administration, 44(3 - 4), 5 - 10. doi:10.1300/J111v44n03_02

Courtney, K. (2006). Library/vendor relations: An academic publisher's perspective. Journal of Library Administration, 44(3-4), 57-68. doi:10.1300/J111v44n03_06

Flowers, J. (2004). Specific tips for negotiations with library materials vendors depending upon acquisitions methods. Libraries Collections, Acquisitions, \& Technical Services, 28(4), 436. doi:10.1080/14649055.2004.10766015

Ginanni, K., McKee, A. E., Wilson, J., \& Brown, L. A. (2015, May 19). Yer doin' it wrong: How NOT to interact with vendors, publishers, or librarians. The Serials Librarian, 68(1 - 4), 255. doi:10.1080/0361526X.2015.1023131

Gruenberg, M. (Ed.). (2014). Both sides now: Vendors and librarians-Managing the negotiation process with library vendors. Against the Grain, 26(6), $84-85$.

Kitchen, J. (2011). Vendor relations: Tales from a vendee. Legal Information Management, 11(1), 17 - 19. doi:10.1017/S1472669611000089 
Ostergaard, K., \& Rossmann, D. (2016). Vendor relations strategies for libraries. Against the Grain, 27(6), $14-16$.

Raley, S., \& Smith, J. (2006). Community college/library vendor relations: You can't always get what you want ... or can you? Journal of Library Administration, 44(3 4), 187 - 202. doi:10.1300/J111v44n03_15

Remy, C. (2013). Libraries are from Mars and vendors are from Venus? Understanding one another better to achieve common goals. Journal of Electronic Resources Librarianship, 25(3), 234. doi:10.1080/1941126X.2013.813318

Tenopir, C. (2005). Vendor communication. Library Journal, 130(10), 42.

Walther, J. H. (1998). Assessing library vendor relations: A focus on evaluation and communication. The Bottom Line, 11(4), 149 - 157.

doi:10.1108/08880459810242380

\section{Appendix A}

\section{Library-Vendor Relations: A survey for vendors}

Q1 These survey results will be used to evaluate profession-wide trends in the library-vendor relationship. This survey is intended for vendor employees that interact regularly with library personnel for sales and support. This survey IS NOT intended for vendor employees such as company owners, upper management, financial managers, technical support personnel, and programmers. Participation is in this survey is voluntary. You can choose to not answer any question that you do not want to answer, and you can stop at any time.

Q2 What is your position at your company?

- $\quad$ Sales representative (1)

- Account manager (2)

- Regional manager (3)

- Other (4)

Q3 How do you gather information about your library customers? Select all that apply.

- Reviewing the Library's web site (1)

- $\quad$ Looking at internal systems for purchasing history (2)

- Checking the news for changes in the budget for the states in which the library is located (3)

- Talking with librarians at the institution (4)

- Other (5)

Q4 What would help you better understand a library's specific needs? Q5 What would help you more efficiently understand a library's specific needs?

Q6 How does your company pass on information to new sales/customer service representatives assigned to existing clients? Select all that apply.

- Internal database information (1)

- Cross-training with previous representatives (2) 
- Begin from scratch with new representatives (3)

- Other (5)

Q7 Do you have an MLIS or equivalent degree?

- Yes (1)

- $N o(2)$

Q8 Have you ever worked in a library?

- Yes (1)

- No (2)

Q9 How often do you contact customers?

- Never (1)

- Once a year (2)

- Once every 6 months (3)

- Once a quarter (8)

- Once a month (4)

- 2-3 Times a month (5)

- Once a week (6)

- Other (7)

Q10 Does your company have a preferred method for you to contact customers? Select all that apply.

- Email (1)

- Telephone (2)

- Mail (3)

- In person site visit (4)

- In person meetings at professional conferences (5)

- Web conference (6)

- Other (7)

- No Preference (9)

Q11 What is your personal preferred method for contacting customers? Select all that apply.

- Email (1)

- Telephone (2)

- Mail (3)

- In person site visit (4)

- In person meetings at professional conferences (5)

- Web conference (6)

- Other (7)

- No preference (8)

Q12- Display this question if:

Answer If Does your company have a preferred method for you to contact customers? In person site visit Is Selected

Or

Does your company have a preferred method for you to contact customers? In person meetings at professional conferences Is Selected Or

What is your personal preferred method for contacting customers? In person site visit Is Selected

Or

What is your personal preferred method for contacting customers? In person meetings at professional conferences Is Selected

Q12 Please rank your top priorities of what you hope to gain from your meetings with libraries (1 is most important, 6 is least) 
Information about new products (1)

Training and information for existing subscriptions (2)

Sharing company information such as news and updates about the

organization (3)

Socializing with library employees (4)

Making sales (5)

Getting customer feedback on existing products and services (6)

Q13 When working with new customers, do you routinely determine their preferred method of communication?

- Yes (4)

- No (5)

- I only gather this information if it is suggested by the library (6)

- Other (3)

Q14 When contacting customers, what falls within the scope of your role?

Select all that apply.

- To sell products and/or subscriptions (1)

- To advertise new products or services (3)

- To share news of product or platform updates (4)

- To learn about current and upcoming needs of customers (6)

- Other (5)

Q15 What services does your company's management system include?

Select all that apply.

- Automatic invoicing (1)

- Payment history (2)

- Subscription collection details (entitlement reports) (3)

- Customer preferences for communication (4)

- Notes (6)

- Other (7)

Q16 How familiar are you with the following?

\begin{tabular}{|c|c|c|c|}
\hline $\begin{array}{c}\text { Unfamiliar } \\
(1)\end{array}$ & $\begin{array}{c}\text { Somewhat } \\
\text { familiar (2) }\end{array}$ & $\begin{array}{c}\text { Familiar } \\
(3)\end{array}$ \\
\hline $\begin{array}{c}\text { Whe mission of academic } \\
\text { libraries (1) }\end{array}$ & $\bullet$ & $\bullet$ & $\bullet$ \\
services (2) & $\bullet$ & $\bullet$ & $\bullet$ \\
\hline Link resolvers (3) & $\bullet$ & $\bullet$ & $\bullet$ \\
\hline KnowledgeBases (4) & $\bullet$ & $\bullet$ & $\bullet$ \\
\hline Metadata/Indexing (5) & $\bullet$ & $\bullet$ & $\bullet$ \\
\hline
\end{tabular}

Q17 Which methods are used by your company to establish subscription and purchase prices for libraries? Select all that apply.

- Library type (community college, four year undergraduate, $\mathrm{PhD}$ granting, public, private, etc.) (5)

- Full Time Equivalency (FTE) (1)

- Carnegie Classification (2)

- Materials budget (3)

- Prices are the same for all libraries (10)

- Degree programs offered (11)

- Other (4) 
Q18 What types of discounts does your company offer? Select all that apply.

- End-of-calendar year sales (3)

- End-of-fiscal year sales (4)

- New product discounts (5)

- Purchases of multiple products (6)

- Purchases by groups of libraries/consortia (7)

- Holidays (8)

- Customer loyalty (10)

- Multi-year commitment (11)

- Other (9)

Q19 What pressures do you face in your work? Select all that apply.

- Higher sales volume (1)

- More regular contact with customers (2)

- Responding to customer service requests (3)

- Price negotiations (4)

- Travel to conferences and customer sites (5)

- Managing the varying needs of different kinds of academic libraries (6)

- Keeping current with my company's products (7)

- Internal issues (i.e. product functionality, messaging, customer focus) (9)

- Other (8)

Q20 We would like to follow-up with a few respondents to do short interviews about library-vendor relations. If you would be willing to be contacted for a brief interview, please enter your name and email address below. We will store your survey responses and your email address separately so as to keep your survey answers confidential.

\section{Appendix B}

\section{Library-Vendor Relations: A survey for libraries - Final}

Q1 These survey results will be used to evaluate profession-wide trends in the library-vendor relationship. This survey is intended for library employees that interact regularly with vendors. Participation in this survey is voluntary. You can choose not to answer any question that you do not want to answer, and you can stop at any time.

Q2 Is your academic institution public or private?

- Public (1)

- Private (2)

Q3 What is the size of your institution? (FTE Enrollment)

- Less than $1,000(1)$

- $1,000-2,999(2)$

- $3,000-4,999(3)$

- $5,000-9,999(4)$

- $10,000-19,999(5)$

- 20,000 or more (6)

Q4 What is your institution's Carnegie classification?

- Associate's Colleges (1)

- Doctorate-granting Universities (2) 
- Master's Colleges and Universities (3)

- Baccalaureate Colleges (4)

- Special Focus Institutions (5)

- Tribal Colleges (6)

Q5 In which state do you currently reside?

- Alabama (1)

- Alaska (2)

- Arizona (3)

- Arkansas (4)

- California (5)

- Colorado (6)

- Connecticut (7)

- Delaware (8)

- District of Columbia (9)

- Florida (10)

- Georgia (11)

- Hawaii (12)

- Idaho (13)

- Illinois (14)

- Indiana (15)

- Iowa (16)

- Kansas (17)

- Kentucky (18)

- Louisiana (19)

- Maine (20)

- Maryland (21)

- Massachusetts (22)

- Michigan (23)

- Minnesota (24)

- Mississippi (25)

- Missouri (26)

- Montana (27)

- Nebraska (28)

- Nevada (29)

- New Hampshire (30)

- New Jersey (31)

- New Mexico (32)

- New York (33)

- North Carolina (34)

- North Dakota (35)

- Ohio (36)

- Oklahoma (37)

- Oregon (38)

- Pennsylvania (39)

- Rhode Island (40)

- South Carolina (41)

- South Dakota (42)

- Tennessee (43)

- Texas (44)

- Utah (45)

- Vermont (46)

- Virginia (47) 
- Washington (48)

- West Virginia (49)

- Wisconsin (50)

- Wyoming (51)

- I do not live in the continental United States (52)

Q6 How do you acquire your resources? Select all that apply.

- Independently and directly from vendors (3)

- Both independently and through consortia (4)

- Solely through consortia (5)

- With partner libraries, not formally in a consortia (6)

- Through cooperative, non-profit organizations (8)

- Other (7)

Q7 What is the size of your FY15/16 materials budget?

- $\$ 0-\$ 49,999$ (1)

- $\$ 50,000-\$ 149,000(2)$

- $\$ 150,000-\$ 499,999(3)$

- $\$ 500,000-\$ 1,999,999(4)$

- $\$ 2,000,000-\$ 4,999.999(5)$

- $\$ 5,000,000-\$ 9,999,999(6)$

- $\$ 10,000,000$ or more (7)

Q8 How many people in your library communicate regularly with vendors?

- $1(1)$

- $2(2)$

- $3(3)$

- $4(4)$

- $5+(5)$

Q9 With roughly how many vendors do you work?

- Less than $5(1)$

- $5-9(2)$

- $10-14(3)$

- $15-24(4)$

- $25+(5)$

Q10 What subscription agency do you use to manage some or all of your subscription resources, if at all?

- Basch (1)

- $\operatorname{Ebsco}(2)$

- Harrassowitz (3)

- Prenax (4)

- Other (5)

- We do not use a subscription agency (6)

Q11 How do you manage electronic resources, billing, and vendor information? Select all that apply.

- Electronic Resources Management System (ERMS) (1)

- $\quad$ Spreadsheet (2)

- Other (3)

Q12 How do you communicate with vendors? Select all that apply.

- Email (1)

- Telephone (2)

- Teleconference (3)

- In person visits (4)

- Postal Mail (6)

- Other (7) 
Q13 Do you allow on-campus site visits from vendors?

- Yes (1)

- $\quad$ No (2)

Q14 Do you meet with vendors at professional conferences?

- Yes (1)

- No (2)

Q15- Display this question if:

Answer If Do you allow on-campus site visits from vendors? Yes Is Selected Or

Do you meet with vendors at professional conferences? Yes Is Selected

Q15 Please rank your top priorities of what you hope to gain from your meetings with vendors ( 1 is most important, 6 is least). Drag to reorder. Information about new products (1) Training and information for existing subscriptions (2) Conveying library information, technology, and priorities to vendor

(3) Socializing with vendor representative (4) Negotiating prices (5) Providing feedback to vendor on existing products and services (6) Q16- Display this question if: Answer If Do you allow on-campus site visits from vendors? Yes Is Selected Or

Do you meet with vendors at professional conferences? Yes Is Selected

Q16 Do you explain these preferences to vendors prior to meeting with them?

- Yes (1)

- No (2)

Q17 For each of the following, what is your most preferred form of communication?

\begin{tabular}{|c|c|c|c|c|c|c|}
\hline & $\begin{array}{c}\text { Email } \\
(1)\end{array}$ & $\begin{array}{c}\text { Teleph } \\
\text { one (2) }\end{array}$ & $\begin{array}{c}\text { Posta } \\
\text { I mail } \\
(3)\end{array}$ & $\begin{array}{c}\text { Site } \\
\text { visit } \\
(4)\end{array}$ & $\begin{array}{c}\text { Professi } \\
\text { onal } \\
\text { conferen } \\
\text { ce (5) }\end{array}$ & $\begin{array}{c}\text { Teleconfer } \\
\text { ence (6) }\end{array}$ \\
\hline $\begin{array}{c}\text { Receiving } \\
\text { information } \\
\text { about new } \\
\text { resource(s) } \\
(1)\end{array}$ & $\bullet$ & $\bullet$ & $\bullet$ & $\bullet$ & $\bullet$ & $\bullet$ \\
\hline $\begin{array}{c}\text { Inquiring of } \\
\text { vendor } \\
\text { about new } \\
\text { resource(s) } \\
\text { (2) }\end{array}$ & $\bullet$ & $\bullet$ & $\bullet$ & $\bullet$ & $\bullet$ & $\bullet$ \\
\hline $\begin{array}{c}\text { Setting up } \\
\text { resource } \\
\text { trials (3) }\end{array}$ & $\bullet$ & $\bullet$ & $\bullet$ & $\bullet$ & $\bullet$ & $\bullet$ \\
\hline
\end{tabular}




\begin{tabular}{|c|c|c|c|c|c|c|}
\hline $\begin{array}{l}\text { Receiving } \\
\text { new or } \\
\text { updated } \\
\text { license } \\
\text { agreement } \\
\text { s (4) }\end{array}$ & • & • & • & • & • & • \\
\hline $\begin{array}{c}\text { Troublesho } \\
\text { oting } \\
\text { access } \\
\text { problems } \\
\text { (5) }\end{array}$ & • & • & • & • & • & • \\
\hline $\begin{array}{l}\text { Receiving } \\
\text { an invoice } \\
\text { (6) }\end{array}$ & • & • & • & • & • & • \\
\hline $\begin{array}{l}\text { Offers for } \\
\text { training } \\
\text { and } \\
\text { marketing } \\
\text { of currently } \\
\text { owned or } \\
\text { subscribed } \\
\text { products } \\
(7)\end{array}$ & • & • & • & • & • & • \\
\hline
\end{tabular}

Q18 For each of the following, what is your least preferred form of communication?

\begin{tabular}{|c|c|c|c|c|c|c|}
\hline & $\begin{array}{c}\text { Email } \\
(1)\end{array}$ & $\begin{array}{c}\text { Teleph } \\
\text { one (2) }\end{array}$ & $\begin{array}{c}\text { Posta } \\
\text { I mail } \\
(3)\end{array}$ & $\begin{array}{c}\text { Site } \\
\text { visit } \\
(4)\end{array}$ & $\begin{array}{c}\text { Professi } \\
\text { onal } \\
\text { conferen } \\
\text { ce (5) }\end{array}$ & $\begin{array}{c}\text { Teleconfer } \\
\text { ence (6) }\end{array}$ \\
\hline $\begin{array}{c}\text { Receiving } \\
\text { information } \\
\text { about new } \\
\text { resource(s) } \\
(1)\end{array}$ & $\bullet$ & $\bullet$ & $\bullet$ & $\bullet$ & $\bullet$ & $\bullet$ \\
\hline $\begin{array}{c}\text { Inquiring of } \\
\text { vendor } \\
\text { about new } \\
\text { resource(s) } \\
\text { (2) }\end{array}$ & $\bullet$ & $\bullet$ & $\bullet$ & $\bullet$ & $\bullet$ & $\bullet$ \\
\hline $\begin{array}{c}\text { Setting up } \\
\text { resource } \\
\text { trials (3) }\end{array}$ & $\bullet$ & $\bullet$ & $\bullet$ & $\bullet$ & $\bullet$ & $\bullet$ \\
\hline $\begin{array}{c}\text { Receiving } \\
\text { new or } \\
\text { updated } \\
\text { license } \\
\text { agreement } \\
\text { s (4) }\end{array}$ & $\bullet$ & $\bullet$ & $\bullet$ & $\bullet$ & $\bullet$ & $\bullet$ \\
\hline
\end{tabular}




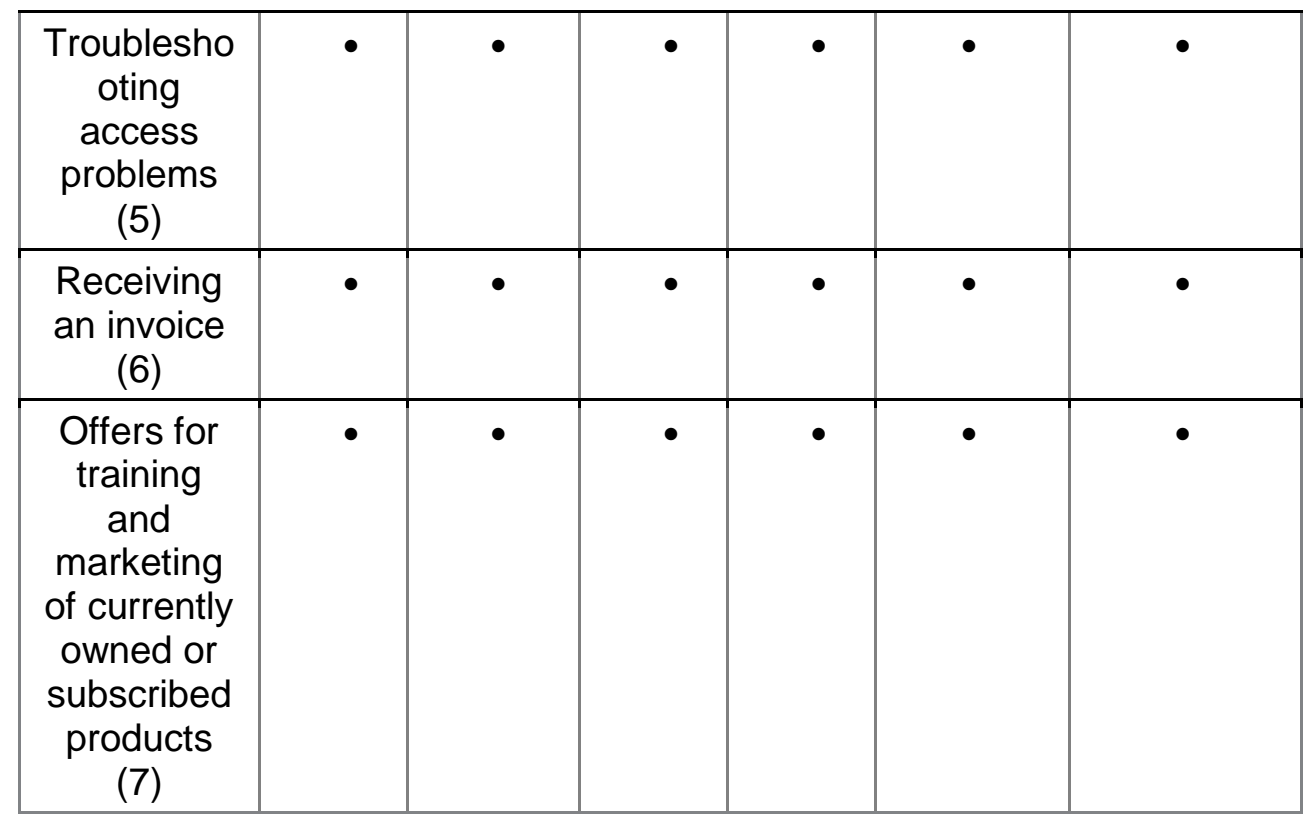

Q19 How do you relay communication preferences to vendors?

- By email (1)

- In conversation with a vendor (2)

- Sharing library/vendor policies via a library webpage (3)

- Other (4)

- N/A (5)

Q20 We would like to follow-up with a few respondents to do short interviews about library-vendor relations. If you would be willing to be contacted for a brief interview, please enter your name and email address below. We will store your survey responses and your email address separately so as to keep your survey answers confidential. 